\title{
Penggunaan Modul MMFE untuk Meningkatkan Efikasi Diri Bahasa Inggris Siswa SMP
}

\author{
Arfi Nurul Hidayah ${ }^{1} \mathcal{E}$ Asmadi Alsa ${ }^{2}$ \\ Fakultas Psikologi Universitas Gadjah Mada Yogyakarta
}

\begin{abstract}
The differences of subject load and limited ability of students in learning English give uncertainty to student of class VII in studying it. Uncertainty themselves (self-efficacy) could decrease the willingness of the students to gain expected achievement. This study aims to examine the effect of using Mind mapping Module for English (MMFE) in improving student's English self-efficacy on class VII. This research is a module validation through the method of quasi experimental design with untreated control group design with pretest and posttest dependent samples. The subjects were 31 students of class VII. Collecting data using english self-efficacy scale, comprehension test as manipulation checks, and MMFE module. Aiken's V statistic test was used to test the validity coefficient contents of module, while the mixed anova test was used to test the effect of MMFE module towards english self-efficacy. The result showed MMFE module valid by content and empiric to improving english self-efficacy of class VII students $(\mathrm{F}=5,433, \mathrm{p}<0,05)$.
\end{abstract}

Keywords: english self efficacy, junior high school, mind map

Abstrak. Perbedaan beban mata pelajaran serta masih terbatasnya pengetahuan berpengaruh terhadap ketidakyakinan siswa kelas VII SMP dalam menghadapi pelajaran Bahasa Inggris. Ketidakyakinan diri (efikasi diri) dapat mengakibatkan rendahnya usaha mencapai prestasi yang diharapkan. Penelitian ini bertujuan menguji pengaruh penggunaan modul mind map for English (MMFE) dalam meningkatkan efikasi diri bahasa Inggris siswa kelas VII SMP. Penelitian ini merupakan validasi modul melalui metode eksperimen kuasi dengan desain untreated control group design with dependent pretest and posttest samples. Subjek penelitian adalah 31 siswa kelas VII SMP. Pengumpulan data menggunakan Skala Efikasi Diri Bahasa Inggris, tes pemahaman sebagai cek manipulasi, dan modul MMFE. Uji statistik Aiken's V digunakan untuk menguji koefisien validitas isi modul, sedangkan uji mixed anova untuk menguji secara empirik pengaruh modul MMFE terhadap efikasi diri bahasa Inggris. Hasil penelitian menunjukkan modul MMFE valid secara isi dan empirik untuk meningkatkan efikasi diri bahasa Inggris siswa kelas VII $\operatorname{SMP}(F=5,433, \mathrm{p}<0,05)$.

Kata kunci: efikasi diri Bahasa Inggris, mind map, siswa SMP

Masa transisi dari jenjang sekolah dasar

\footnotetext{
${ }^{1}$ Korespondensi mengenai isi artikel ini dapat dilakukan melalui: arfi.nurulhidayah@mail.ugm.ac.id

2 Atau melalui asmalsa@ugm.ac.id

E-JURNAL GAMA JPP
}

menuju sekolah menengah pertama merupakan masa yang cukup kritis bagi siswa (Puspasari, Kuwato, \& Wijaya, 2012; Santrock, 2011). Masa kritis ini 
dikarenakan siswa-siswa kelas VII SMP mengalami perubahan pada berbagai aspek kehidupannya secara sekaligus dalam waktu yang bersamaan. Santrock (2011) menjelaskan beberapa hal yang dialami siswa kelas VII SMP ialah adanya perubahan fisik; perubahan struktur sekolah; perubahan guru; bertambahnya materi pelajaran; dan perubahan fungsi kognitif menjadi tahap formal-operasional. Berbagai perubahan di tahun pertama SMP ini dapat menyulitkan bagi banyak siswa.

Salah satu perubahan yang siswa kelas VII hadapi ialah adanya perubahan materi pelajaran. Di jenjang sekolah yang baru, siswa mendapatkan beberapa mata pelajaran yang berbeda dari jenjang sebelumnya. Masa transisi ini dapat menjadi lebih berat jika siswa menghadapi mata pelajaran yang sulit. Salah satu mata pelajaran yang dianggap sulit oleh siswa ialah Bahasa Inggris (Rahmatiah, 2014; Rita \& Situmorang, 2014; Yanuswantoro, 2015). Berdasarkan hasil UN SMP di provinsi Yogyakarta tahun ajaran 2014/2015 menunjukkan bahwa dari 100 sekolah di provinsi Yogyakarta, terdapat 45 sekolah yang mendapatkan rata-rata nilai Bahasa Inggris terendah dibandingkan nilai UN dari mata pelajaran Bahasa Indonesia, IPA, dan Matematika.

Bahasa Inggris merupakan bahasa asing bagi siswa di Indonesia. Meskipun demikian, bahasa Inggris merupakan salah satu pelajaran yang harus dikuasai oleh siswa di zaman globalisasi seperti sekarang. Oleh karena itu dibutuhkan berbagai strategi agar siswa mampu menguasai bahasa Inggris dengan lebih baik lagi.

Bahasa Inggris mulai diperkenalkan di jenjang Sekolah Dasar sejak tahun 1994. Sejak tahun ajaran 2013/2014 kurikulum 86 pendidikan di Indonesia mengalami perubahan. Kementerian Pendidikan dan Kebudayaan mulai menghapuskan Bahasa Inggris dari kurikulum di SD (Permendikbud No. 64 Tahun 2013). Penghapusan ini menjadikan Bahasa Inggris tidak lagi memiliki suatu standar kompetensi yang rinci sebagai salah satu mata pelajaran muatan lokal di SD. Ketentuan penghapusan ini membuat pelajaran Bahasa Inggris di SD diarahkan sebagai pengenalan dan tidak memiliki standar ketuntasan yang wajib dipenuhi.

Pada sekolah menengah pertama, Bahasa Inggris merupakan suatu mata pelajaran wajib bagi siswa. Bahasa Inggris memiliki suatu standar ketuntasan seperti mata pelajaran lainnya (Permendikbud No. 24 Tahun 2016). Selain itu, Bahasa Inggris juga merupakan salah satu mata pelajaran yang diujikan saat Ujian Nasional di kelas IX. Kondisi baru seperti ini menuntut siswa kelas VII untuk mampu mengikuti pelajaran Bahasa Inggris dengan baik supaya dapat mencapai Kriteria Ketuntasan Minimal (KKM) yang ditetapkan.

Dalam pencapaian ketuntasan mata pelajaran Bahasa Inggris, masih ditemui beberapa kendala. Berdasarkan wawancara dengan Guru Bahasa Inggris kelas VII di SMP X Yogyakarta pada Januari 2016 dan hasil angket terhadap 101 siswa kelas VII di SMP X Yogyakarta pada Juli 2016, didapatkan hasil bahwa kebanyakan siswa masih mengeluhkan sulitnya memahami materi pelajaran Bahasa Inggris. Siswa sulit memahami arti kosakata (vocabulary), sulit menghafalkan kosakata, dan belum mampu menyusun kalimat dengan baik. Kebanyakan siswa juga cenderung untuk menunda pengerjaan tugas. Di tiap kelas, selalu ada siswa yang masih kesulitan dan kurang aktif dalam mengikuti pelajaran. Beberapa siswa ada yang baru E-JURNAL GAMA JPP 
mendapatkan pelajaran Bahasa Inggris saat di SMP ini. Berdasarkan nilai UAS dan UTS, terlihat masih banyak siswa yang mendapatkan nilai di bawah KKM. Guru biasa melakukan remedial berulang kali dengan memberikan tugas tambahan jika siswa tidak mencapai KKM.

Berdasarkan temuan studi pendahuluan di atas, didapatkan dinamika permasalahan siswa sebagai berikut; (1) kesulitan siswa dalam mengikuti pelajaran Bahasa Inggris diawali karena munculnya ketidakyakinan untuk mampu memahami materi pelajaran yang dianggap asing tersebut; (2) Ketidakyakinan siswa terkait kemampuan untuk memahami materi memberikan pengaruh terhadap kurangnya komitmen dalam pengerjaan tugas. Saat mendapatkan tugas, kebanyakan siswa mengerjakan seadanya dan kurang sungguh-sungguh; (3) Kesulitan menghadapi pelajaran bahasa Inggris dianggap suatu hal yang biasa sehingga siswa belum melakukan usaha yang sungguh-sungguh.

Permasalahan yang dialami siswa kelas VII SMP tersebut dapat dijabarkan menggunakan perspektif sosial kognitif. Dalam perspektif sosial kognitif, suatu pembentukan perilaku didapat dari interaksi timbal balik antara determinan individu (person), perilaku (behavior), dan lingkungan (environment). Interaksi timbal balik ini biasa disebut dengan triadic reciprocality (Bandura, 1997). Perilaku siswa ketika menghadapi pelajaran Bahasa Inggris dipengaruhi oleh determinan individu (pikiran dan perasaan yang terkait dengan bahasa Inggris) dan determinan lingkungan (metode pengajaran dari guru).

Permasalahan yang telah dijelaskan di atas menunjukkan bahwa kesulitan siswa terkait pelajaran bahasa Inggris didahului dengan adanya ketidakyakinan terhadap kemampuan diri untuk E-JURNAL GAMA JPP memahami materi dan menyelesaikan soal bahasa Inggris. Hal ini menunjukkan bahwa keyakinan siswa memiliki peran yang penting dalam perilaku memahami dan mengerjakan soal bahasa Inggris. Menurut Bandura (1997), keyakinan diri yang mendasari terbentuknya suatu perilaku disebut dengan istilah efikasi diri.

Efikasi diri merupakan suatu penilaian pribadi individu terhadap kemampuan dalam domain aktivitas, bukan dalam domain sifat umum (Yapono \& Suharnan, 2013). Menurut Baron \& Byrne (2004) efikasi diri dibagi menjadi tiga macam yaitu efikasi diri akademik, efikasi regulasi diri, dan efikasi diri sosial. Efikasi diri akademik adalah efikasi dalam hal kemampuan mengerjakan tugas, mengatur aktivitas belajar, dan mencapai ekspektasi. Efikasi regulasi diri merupakan efikasi dalam hal kemampuan menahan tekanan sebaya dan menghindari aktivitas beresiko tinggi. Sedangkan efikasi diri sosial adalah efikasi dalam hal membentuk dan mempertahankan hubungan, menjadi asertif, dan ikut serta dalam waktu luang.

Efikasi diri merupakan suatu proses evaluasi secara kognitif dan bersifat unidimensional (Baron \& Byrne, 2004). Hal ini berarti tingkatan efikasi diri yang dimiliki individu terbatas pada suatu hal yang khusus. Siswa dengan efikasi diri rendah pada suatu bidang, dapat memiliki efikasi diri yang tinggi dalam bidang lainnya. Misalnya, seorang siswa memiliki efikasi diri yang lebih tinggi pada pelajaran Olahraga dibandingkan dengan pelajaran Bahasa Inggris. Topik penelitian ini difokuskan pada efikasi diri akademik, khususnya pada mata pelajaran Bahasa Inggris.

Efikasi diri bahasa Inggris dapat diartikan sebagai penilaian terhadap kemampuan diri dalam mempelajari 
Bahasa Inggris (Rahemi, 2007). Hal yang serupa dijelaskan oleh Wang dan Pape (2007) bahwa efikasi diri bahasa Inggris merujuk pada penilaian individu terhadap apa yang bisa mereka lakukan dengan kemampuan yang dimiliki dan bukan penilaian terhadap kemampuan tersebut.

Beberapa penelitian telah menunjukkan bahwa efikasi diri bahasa Inggris memberikan pengaruh dalam pencapaian prestasi siswa (Mahyuddin, Elias, Cheong, Muhamad, Noordin, \& Abdullah, 2006; Ersanli, 2015; Magogwe \& Oliver, 2007; Ellsworth \& Seguin, 2009). Siswa yang memiliki efikasi diri tinggi akan efektif menghadapi tantangan, memiliki kepercayaan penuh dengan kemampuan diri, cepat menghadapi masalah dan mampu bangkit dari kegagalan (Bandura dalam Yapono \& Suharnan, 2013).

Tinggi rendahnya efikasi diri menurut Bandura (1997) dipengaruhi oleh empat sumber berikut; (1) mastery experience yaitu pengalaman masa lalu yang terkait dengan kesuksesan atau kegagalan dalam menghadapi suatu tugas; (2) vicarious experience yaitu hasil pengamatan terhadap lingkungan sekitar (3) verbal persuasion yaitu segala hal yang disampaikan orang lain kepada individu (4) physical and emotional state yaitu tekanan, gairah, reaksi ketakutan, kelelahan, dan rasa sakit saat menunjukkan perilaku.

Berdasarkan hasil studi pendahuluan, dinamika permasalahan yang dialami siswa kelas VII berkaitan dengan sumber-sumber efikasi diri. Siswa menganggap bahwa kemampuannya dalam bahasa Inggris masih kurang karena masih terbatasnya pengalaman yang dimiliki dalam mempelajari bahasa asing ini (mastery experience). Siswa merasa banyak teman sekelasnya yang juga 88 mengalami kesulitan dalam memahami bahasa Inggris, sehingga siswa tidak mengeluarkan usaha terbaiknya dalam belajar (vicarious experience). Saat menemui kesulitan dalam mengerjakan soal, siswa kurang mendapatkan dukungan secara lisan dari sekitarnya untuk lebih berusaha sungguh-sungguh (verbal persuasion). Pada akhirnya, siswa merasa cemas dan tidak yakin saat diminta mengerjakan soal bahasa Inggris (physical and emotional state).

Salah satu hal mendasar yang diperlukan dalam pembelajaran bahasa Inggris menurut Chamot (dalam Rahemi, 2007) adalah memiliki kepercayaan diri yang tinggi untuk mampu mengerjakan tugas yang diberikan. Kim, Wang, Ahn, \& Bong (2015) menambahkan bahwa siswa yang memiliki efikasi diri tinggi akan lebih sering menerapkan strategi belajar untuk mencapai tujuan yang ingin dicapainya.

Jinks dan Morgan mengembangkan aspek-aspek efikasi diri akademik berdasarkan teori efikasi diri Bandura yaitu talent, effort, dan context. Talent adalah keyakinan individu terhadap kemampuan dan bakat yang dimilikinya terkait dengan kemampuan akademik. Effort merupakan usaha yang dilakukan individu dalam melaksanakan tugas dan pekerjaan yang terkait dengan akademik. Context yaitu keyakinan individu dalam menghadapi situasi-situasi yang terkait dengan akademik. Dalam penelitian ini, ketiga aspek tersebut akan digunakan sebagai landasan untuk melihat sejauh mana efikasi diri akademik siswa.

Efikasi diri terhadap suatu mata pelajaran dapat dipengaruhi oleh interaksi sosial di kelas. Salah satu interaksi sosial yang terjadi di kelas adalah interaksi antara guru dan murid. Rahemi (2007) menyebutkan bahwa metode pembelajaran merupakan salah satu faktor yang memengaruhi pencapaian prestasi E-JURNAL GAMA JPP 
Bahasa Inggris. Hal ini berarti metode pembelajaran memiliki pengaruh terhadap efikasi diri siswa. Metode pembelajaran yang masih menggunakan media ceramah dan menulis di papan tulis cenderung memberikan efek yang membosankan bagi siswa (Snowman \& McCown, 2012). Hal ini sesuai dengan hasil dari studi pendahuluan yang menunjukkan bahwa siswa cenderung merasa bosan dengan metode penyampaian pelajaran yang berupa ceramah dan menyalin catatan di papan tulis.

Bahasa Inggris di tingkat SMP merupakan pelajaran yang salah satu tujuannya adalah mengembangkan kompetensi siswa dalam hal berkomunikasi secara lisan dan tulis untuk menyelesaikan permasalahan sehari-hari (Permendikbud No. 24 Tahun 2016). Kemampuan berkomunikasi ini perlu ditunjang oleh kemampuan menggunakan kosa kata, tata bahasa, dan langkahlangkah retorika. Bahasa Inggris membutuhkan metode belajar yang mampu membantu siswa memahami dan mengungkapkan informasi, pikiran, perasaan secara lisan dan tulis.

Metode yang dibutuhkan untuk mempelajari bahasa Inggris tersebut terdapat dalam metode mind map. Mind map adalah suatu metode pembelajaran yang membantu individu menyimpan dan mengatur informasi dengan menggunakan kata kunci, warna, garis, dan gambar secara spesifik sehingga memudahkan otak dalam menyerap informasi yang diterima serta dapat mendorong munculnya pemikiran atau ide baru. Mind map merupakan suatu metode mencatat yang kreatif, efektif, dan secara harfiah berarti memetakan pikiran-pikiran individu (Buzan, 2006).

Peningkatan efikasi diri siswa dalam pelajaran lebih dipengaruhi oleh situasi E-JURNAL GAMA JPP kelas termasuk perubahan metode belajar yang diterapkan. Berdasarkan hasil studi pendahuluan yang telah dilakukan, ditemukan permasalahan siswa merasa sulit untuk memahami dan mengerjakan soal bahasa Inggris yang diberikan guru. Kesulitan yang dialami siswa ini memiliki kaitan dengan bagaimana guru menyampaikan materi pelajaran saat di kelas. Oleh karena itu, untuk mengatasi permasalahan ini diperlukan suatu intervensi berupa perubahan metode belajar dengan menggunakan mind map untuk meningkatkan efikasi diri siswa dalam pelajaran bahasa Inggris.

Fungsi dan manfaat mind map menurut Buzan (2006) adalah membantu perencanaan, berkomunikasi, menjadikan individu lebih kreatif, menyusun dan menjelaskan pikiran, mengingat lebih baik, menyelesaikan masalah, serta belajar lebih cepat dan efisien. Penelitian yang dilakukan Fadhilah dan Nurjayanti (2013) terhadap siswa kelas V SD menunjukkan bahwa metode mind map efektif untuk mengatasi kesulitan mempelajari Bahasa Inggris. Penelitian Liana, Setyadi, \& Herpratiwi (2015) juga menunjukkan bahwa aktivitas siswa dalam pembelajaran menjadi meningkat saat diberikan metode pembelajaran mind map.

Menurut Buran dan Filyukov (2015) metode mind map dapat membantu siswa untuk mengatasi masalah, brain storming ide kreatif, mengingat kosakata baru, mencatat, meningkatkan kemampuan membaca, mengelola tugas, serta menyiapkan presentasi. Metode mind map juga dapat mempermudah siswa untuk mempelajari suatu topik baru secara lebih menarik (Kiong, Yunos, Mohammad, Othman, Heong, \& Mohammad, 2011). Dalam mind map, siswa lebih mudah mengasosiasikan beragam informasi dalam suatu konsep yang utuh (Zipp dan 
Maher, 2013). Pembuatan mind map secara individual memungkinkan siswa lebih mudah untuk menyerap kembali materi pelajaran dibandingkan dengan pembuatan mind map yang hanya mencontoh guru (Fun dan Maskat, 2010).

Intervensi dalam penelitian ini menggunakan modul Mind Map for English (MMFE). Modul MMFE merupakan pengembangan dari modul metode mind map dalam pembelajaran Matematika (Nurani, 2015). Peneliti menyesuaikan isi modul dengan materi pelajaran bahasa Inggris sesuai silabus yang diberikan guru. Pengembangan modul yang dilakukan oleh peneliti melalui proses validasi secara dua tahap. Tahapan validasi modul menurut Russel (dalam Ahmad, Amat, Yahya, Yusof, dan Alias, 2011) yaitu validasi isi modul dan uji validitas secara empirik. Uji validitas isi dilakukan dengan cara meminta para ahli yang kompeten untuk menilai isi modul. Setelah dilakukan penilaian, modul kemudian diujicobakan di lapangan untuk mengetahui validitas empiriknya.

Modul MMFE berisikan penerapan metode pembelajaran mind map melalui empat langkah (Buzan, 2006) yaitu (1) overview, tinjauan menyeluruh terhadap suatu topik pada saat pembelajaran baru dimulai; (2) preview, tinjauan awal berupa gambaran umum setingkat lebih detail dari overview sehingga siswa memahami sub topik; (3) inview, tinjauan mendalam atau inti dari proses belajar dengan membahas topik secara rinci; (4) review, tinjauan ulang di awal atau menjelang berakhirnya proses belajar mengajar dengan memberikan penekanan pada informasi, konsep, atau rumus penting yang harus dikuasai siswa. Tahapan intervensi penelitian juga menggunakan aspek penerapan pembelajaran dengan pendekatan sosial kognitif menurut 90
Snowman dan McCown (2012) yaitu (1) penyampaian tujuan dan target pembelajaran; (2) pemusatan perhatian; (3) pengorganisasian informasi; pengulangan informasi; dan (5) aktivitas siswa sebagai bentuk proses encoding long term memory (LTM).

Penelitian yang dilakukan mendasarkan pada kerangka kerja teori sosial kognitif dengan menggunakan konsep belajar melalui pengamatan (observational learning) menurut Bandura. Efikasi diri dapat meningkat dengan cara mengamati perilaku orang lain, terutama jika berada dalam situasi, karakteristik, dan mendapat tingkat kesulitan tugas yang sama (Bandura, 1997). Proses intervensi dilakukan pada subjek dengan jenjang yang sama yaitu siswa kelas VII SMP, situasi yang sama yaitu pelajaran Bahasa Inggris, dan memperoleh tugas yang sama berupa materi Bahasa Inggris dalam bentuk mind map. Siswa mengamati guru dalam menerapkan mind map serta mengamati lingkungan kelasnya ketika mengerjakan tugas menggunakan mind map.

Hipotesis yang diajukan untuk penelitian ini adalah penggunaan modul Mind Map For English (MMFE) dapat meningkatkan efikasi diri Bahasa Inggris siswa. Penelitian ini memiliki tujuan untuk menguji pengaruh penggunaan modul "MMFE" dalam meningkatkan efikasi diri siswa kelas VII SMP pada pelajaran Bahasa Inggris.

Manfaat penelitian secara teoritis adalah sebagai pengembangan teori efikasi diri dan pengembangan metode belajar mind map pada setting kelas terutama dalam pelajaran Bahasa Inggris. Manfaat dari penelitian ini secara praktis adalah menguji validitas modul "MMFE" untuk meningkatkan efikasi diri siswa kelas VII SMP dalam mata pelajaran bahasa Inggris. 
Penelitian ini juga diharapkan dapat menjadi salah satu cara untuk meningkatkan efikasi diri siswa sehingga pada akhirnya siswa mampu mencapai prestasi yang lebih optimal.

\section{Metode}

Identifikasi dan definisi operasional variabel penelitian

Variabel tergantung dalam penelitian ini adalah efikasi diri Bahasa Inggris. Efikasi diri Bahasa Inggris dalam penelitian ini berarti penilaian atas keyakinan siswa bahwa dirinya memiliki kemampuan melaksanakan tugas, memecahkan permasalahan, serta berusaha mencapai hasil belajar Bahasa Inggris. Variabel ini diukur melalui skala efikasi diri Bahasa Inggris yang menggunakan aspek-aspek efikasi diri yaitu keyakinan akan kemampuan (talent), keyakinan dalam usaha menyelesaikan permasalahan (effort), serta keyakinan untuk berhasil dalam situasi dan materi (context). Ketiga aspek efikasi diri tersebut berada dalam konteks mata pelajaran bahasa Inggris.

Variabel bebas dalam penelitian ini adalah penggunaan modul "MMFE" yang bertujuan untuk meningkatkan efikasi diri bahasa Inggris siswa kelas VII SMP. Modul "MMFE" merupakan modul penerapan metode Mind map dalam pembelajaran bahasa Inggris. Mind map adalah suatu metode belajar dengan cara mencatat yang melibatkan kata kunci sebagai bagian utama, gambar, warna, dan cabang untuk menjelaskan hubungan antar satu materi dengan materi lain. Intervensi mind map dalam penelitian terdiri dari proses overview, preview, inview, dan review. Intervensi juga melandaskan pada lima tahap pembelajaran secara observational learning yaitu komunikasi tujuan dan objektivitas, pemusatan E-JURNAL GAMA JPP perhatian, organisasi dan pemaknaan, penyampaian informasi materi, dan aktivitas siswa sebagai proses encoding long-term memory (LTM). Selain itu, sumber-sumber efikasi diri (pengalaman keberhasilan, pengamatan terhadap orang lain, persuasi sosial, serta keadaan fisiologis dan emosional) juga dilibatkan selama proses intervensi.

\section{Subjek penelitian}

Subjek penelitian ini adalah 31 siswa kelas VII SMP yang memiliki skor skala efikasi diri Bahasa Inggris dengan kategori sedang dan mengikuti pelajaran Bahasa Inggris dari awal hingga akhir penelitian. Subjek eksperimen sejumlah 15 orang berasal dari SMPN $X$ dan subjek kontrol sejumlah 16 orang berasal dari SMPN Y. Kedua sekolah yang dijadikan target penelitian ditentukan secara non random dengan melihat kesetaraan dari segi akreditasi dan rata-rata nilai bahasa Inggris siswa.

\section{Instrumen penelitian}

Instrumen penelitian yang digunakan adalah skala efikasi diri Bahasa Inggris yang dimodifikasi dari skala efikasi diri Matematika milik Nurani (2015). Aspek efikasi diri Bahasa Inggris yang diukur mendasarkan pada aspek efikasi diri akademik yang dikembangkan oleh Jinks dan Morgan (dalam Nurani, 2015) yang meliputi tiga hal, yaitu talent, effort, dan context. Alternatif pilihan jawaban dalam skala efikasi diri ini yaitu Sangat Sesuai (SS), Sesuai (S), Tidak Sesuai (TS), dan Sangat Tidak Sesuai (STS). Skala milik Nurani (2015) ini telah melalui uji validitas isi (content validity) dengan menggunakan validitas logis dan menunjukkan nilai Aiken's V antara 0,52 sampai 0,90. Koefisien reliabilitas skala dengan menggunakan Alpha Cronbach 
menunjukkan nilai 0,896 . Jumlah aitem skala milik Nurani (2015) berjumlah 28 dengan indeks beda aitem antara 0,30120,599 .

Setelah melakukan penyesuaian menjadi 34 aitem skala, peneliti melakukan validasi isi menggunakan validitas logis melalui 20 panel expert dan menunjukkan nilai Aiken's $\mathrm{V}$ bergerak dari 0,65 hingga 0,925 yang berarti modul memadai secara isi (Azwar, 2014).

Setelah melalui validasi isi, dilakukan uji coba skala terhadap 121 siswa SMP dengan karakteristik yang sesuai dengan subjek penelitian dan didapatkan nilai Alfa Cronbach 0,911. Aitem skala uji coba mengalami gugur 4 buah, sehingga tersisa 30 aitem skala. Penelitian ini juga menggunakan cek manipulasi berupa lima pertanyaan terbuka terkait dengan konsep dasar dan penggunaan mind map. Jawaban yang benar mendapatkan nilai 1 dan jawaban salah mendapat nilai 0. Pengukuran cek manipulasi dilakukan sebelum dan sesudah pemberian intervensi.

\section{Desain penelitian}

Penelitian ini menggunakan desain eksperimen kuasi yaitu the untreated control group design with dependent pretest and posttest sample. Penempatan subjek ke dalam kelompok eksperimen dan kontrol dilakukan secara tidak acak. Pengukuran pada kedua kelompok dilakukan sebelum dan sesudah perlakuan diberikan. Berdasarkan pertimbangan kode etik penelitian, kelompok kontrol juga mendapatkan intervensi setelah penelitian berakhir.

\section{Intervensi}

Intervensi penelitian yaitu penggunaan modul MMFE pada pelajaran Bahasa Inggris di kelas VII SMP. Modul MMFE 92 dimodifikasi dari modul mind map untuk pelajaran Matematika milik Nurani (2015) yang berisi lima tahap utama penerapan pembelajaran observational learning dan penerapan mind map dalam pembelajaran yang terdiri dari overview, preview, inview, dan review (Buzan, 2006).

Modifikasi yang dilakukan pada modul ialah berupa penyesuaian materi pelajaran serta adanya penambahan media pembelajaran berupa video tentang pembuatan mind map (Noer, 2011). Berdasarkan penelitian Nurani (2015) yang menggunakan metode mind map pada pelajaran Matematika kelas VII SMP, didapatkan hasil $\mathrm{F}=8,007$ dengan nilai $\mathrm{p}<0,01$ dan sumbangan efektif sebesar 57,4 $\%$.

\section{Prosedur penelitian}

Penelitian ini berupa proses validasi modul dengan desain penelitian kuasi eksperimen. Creswell (2012) menjelaskan langkah-langkah yang dilakukan dalam penelitian eksperimen yaitu: memastikan desain penelitian sesuai untuk masalah yang akan diteliti. Penelitian ini menggunakan desain eksperimen karena melakukan manipulasi kondisi pada subjek melalui pemberian perlakuan berupa penggunaan modul MMFE. (2) membuat hipotesis untuk menguji hubungan sebab-akibat dari masalah. Studi pendahuluan terkait efikasi diri Bahasa Inggris dilakukan melalui metode kuesioner terbuka, wawancara, dan data dokumentasi nilai di SMPN " $X$ " Yogyakarta. Berdasarkan data preliminary tersebut, peneliti mengajukan hipotesis penelitian yaitu penggunaan modul MMFE dapat meningkatkan efikasi diri bahasa Inggris siswa SMP. (3) memilih unit eksperimen dan mengidentifikasi partisipan penelitian. Unit eksperimen dalam penelitian ini adalah siswa kelas VII SMPN " $X$ " dan SMPN " $Y$ " sejumlah 31 E-JURNAL GAMA JPP 
orang. Kedua sekolah yang dijadikan target penelitian memiliki kesetaraan dari segi akreditasi dan nilai rata-rata Bahasa Inggris. Selain itu, siswa yang dijadikan subjek penelitian memiliki skor skala efikasi diri Bahasa Inggris dengan kategori sedang. (4) memilih perlakuan eksperimen. Perlakuan eksperimen (intervensi) dikembangkan dari modul metode mind map dalam pembelajaran Matematika yang disusun oleh Nurani (2015). Langkah pengembangan modul menurut Russel (dalam Jamaludin, Sulaiman, Abdullah, \& Shamsuddin, 2009) adalah pertama, menentukan tujuan pembuatan modul. Tujuan dari pembuatan modul ini adalah untuk menerapkan metode mind map dan pembelajaran secara observational learning yang diharapkan dapat meningkatkan efikasi diri bahasa Inggris pada siswa kelas VII SMP. Kedua, mengembangkan instrumen pengukuran yang digunakan. Peneliti melakukan pengembangan instrumen berupa cek manipulasi dan skala efikasi diri bahasa Inggris. Setelah itu, peneliti melakukan uji validitas dan reliabilitas skala sebelum digunakan untuk pretest. Uji validitas skala dilakukan melalui professional judgement oleh 20 panel expert dengan menggunakan analisis Aiken's V. Uji reliabilitas skala menggunakan uji Alpha Cronbach. Ketiga, menganalisis dan menentukan pencapaian performansi yang diharapkan. Peneliti menganalisis dan menentukan pencapaian performansi subjek yang diharapkan setelah mendapatkan intervensi. Keempat, menyusun aktivitas dan media yang dipakai dalam modul. Aktivitas yang dipakai dalam modul merupakan perwujudan pembelajaran secara observational learning dengan menggunakan bantuan metode mind map. Aktivitas dan media yang digunakan E-JURNAL GAMA JPP dalam penelitian ini dimodifikasi dari modul Nurani (2015) dan disesuaikan dengan tujuan penelitian. Kelima, menentukan validitas dan reliabilitas modul. Pelaksanaan eksperimen berupa validasi modul melalui dua tahap menurut Russel (dalam Ahmad et al, 2011) yaitu validasi isi modul dan uji validitas empirik di lapangan. Pengujian validitas isi modul intervensi dilakukan melalui analisis professional judgement secara kualitatif dan kuantitatif (Kaplan \& Saccuzo, 2009). Penilai memberikan rentang skor 1 (Sangat Tidak Sesuai) hingga 5 (Sangat Sesuai) terhadap isi modul. Hasil skor dari beberapa penilai dihitung dengan menggunakan formula Aiken's V (Aiken dalam Azwar, 2014). Analisis kualitatif validitas isi didapatkan dari saran yang diberikan para penilai mengenai isi modul. Setelah proses validasi isi selesai, peneliti melakukan revisi sesuai saran yang diberikan para ahli. Keenam, uji coba modul secara empiric. Uji coba modul secara empirik diwujudkan berupa tahap pelaksanaan eksperimen yaitu penggunaan modul MMFE pada kelompok eksperimen.

\section{Uji coba modul}

Uji coba dilakukan pada kelompok eksperimen dengan membandingkan terhadap kelompok kontrol melalui penelitian kuasi eksperimen. Proses uji coba modul dilakukan dengan tiga tahapan yaitu tahap I: Pretest. Penjaringan calon subjek penelitian menggunakan skala efikasi diri bahasa Inggris di SMPN $X$ Yogyakarta (kelompok eksperimen) dan di SMPN Y Yogyakarta (kelompok kontrol). Pada kelompok eksperimen juga diberikan cek manipulasi berupa tes pemahaman mengenai mind map. Tahap II: Penggunaan modul MMFE dalam KBM bahasa Inggris. Uji coba modul MMFE 
merupakan salah satu tahapan dalam memvalidasi modul. Kelompok eksperimen mendapatkan pembelajaran bahasa Inggris dengan menerapkan modul MMFE sebanyak lima kali pertemuan (5 $\mathrm{x}$ 80 menit). Pembelajaran menyesuaikan rancangan silabus yang telah disusun oleh guru kelas. Modul MMFE disampaikan oleh seorang fasilitator dengan kualifikasi Sarjana Bahasa Inggris dengan pengalaman mengajar minimal 2 tahun, memiliki pengetahuan tentang mind map, dan mampu berkomunikasi efektif dengan siswa kelas VII SMP. Pada kelompok kontrol, fasilitator mengajar dengan menggunakan metode konvensional. Pada proses pelaksanaan juga terdapat observer untuk mengamati interaksi fasilitator dan siswa dalam proses KBM di kelompok eksperimen. Kualifikasi observer adalah mahasiswa magister psikologi profesi yang telah lulus Praktik Kerja Profesi Psikologi (PKPP). Tahap III: Posttest, berupa kegiatan pengisian skala efikasi diri bahasa Inggris dan tes pengetahuan sebagai cek manipulasi. Pada kelompok kontrol, posttest hanya pengisian skala saja. Setelah seluruh intervensi dan posttest dilakukan, peneliti memberikan intervensi serupa pada kelompok kontrol sebagai bentuk tanggung jawab peneliti dan juga bagian dari kode etik penelitian.

\section{Analisis data}

Hasil validasi isi modul yang didapatkan dari professional judgement diolah menggunakan analisis Aiken's V. Sedangkan validitas empirik modul diketahui dari hasil analisis data dengan menguji perbedaan skor efikasi diri Bahasa Inggris antara pretest dengan posttest pada kelompok eksperimen dan kontrol. Analisis data menggunakan analisis mixed anova dengan bantuan program SPSS versi 16.

\section{Hasil}

Uji hipotesis penelitian ini menggunakan uji mixed anova. Berdasarkan hasil mixed anova menunjukkan nilai $\mathrm{F}=5,433(\mathrm{p}<0,05)$ yang berarti terdapat perubahan skor pre menuju post yang berbeda secara signifikan pada kedua kelompok (eksperimen dan kontrol). Hal ini berarti pemberian intervensi berupa penggunaan modul MMFE dapat meningkatkan skor efikasi bahasa Inggris pada kelompok eksperimen. Intervensi modul MMFE dalam penelitian ini memberikan kontribusi sebesar 22,9\% terhadap perubahan efikasi diri bahasa Inggris siswa kelas VII SMP.

Skor pengetahuan mind map (cek manipulasi) pada kelompok eksperimen dianalisis dengan menggunakan Wilcoxon Signed Rank Test. Rerata skor pengetahuan mind map sebelum diberikan perlakuan adalah 0,067 dan skor setelah perlakuan adalah 4,867. Hasil analisis skor pengetahuan mind map diketahui memiliki nilai $\mathrm{z}=-3,626(\mathrm{p}<0,05)$. Hasil tersebut menunjukkan bahwa terdapat perbedaan yang signifikan antara skor pengetahuan mind map sebelum dan sesudah perlakuan pada kelompok eksperimen.

\section{Diskusi}

Hasil penelitian menunjukkan bahwa modul Mind Map For English (MMFE) dapat meningkatkan efikasi diri bahasa Inggris siswa SMP $(F=5,433 ; p<0,05)$. Hal ini berarti terdapat perbedaan yang signifikan antara perubahan skor efikasi diri bahasa Inggris pada kelompok eksperimen dan kelompok kontrol. Perubahan skor efikasi diri bahasa Inggris pada kelompok eksperimen yang menggunakan modul MMFE dalam 
pembelajaran lebih tinggi dibanding kelompok kontrol yang tidak menggunakan modul MMFE. Hal ini sesuai dengan hasil penelitian yang dilakukan Nurani (2015), yaitu penerapan metode mind map dapat meningkatkan efikasi diri Matematika siswa kelas VII SMP.

Pada setiap pertemuan dalam intervensi berisi lima aspek penerapan pembelajaran secara sosial kognitif dan empat langkah penerapan mind map dalam pembelajaran. Tiap pertemuan didahului dengan penyampaian tujuan dan target pembelajaran. Proses pertama ini berisikan pemberian penjelasan tentang deskripsi, manfaat, dan tujuan metode belajar yang digunakan dalam setiap pertemuan. Hal ini ditujukan supaya siswa memiliki gambaran apa yang akan dipelajari dan bagaimana siswa dapat mencapai target di setiap pertemuan. Pada tiap awal pertemuan juga dilakukan review singkat tentang materi yang telah disampaikan sebelumnya.

Selanjutnya, proses kedua yaitu pemusatan perhatian merupakan perwujudan tahapan atensi. Dalam tahap ini berisikan proses untuk menarik perhatian siswa sehingga fokus dan mengikuti pembelajaran secara aktif. Pada tahap kedua ini, fasilitator mulai menyampaikan topik materi secara keseluruhan dengan menggunakan mind map (overview).

Pada tahap selanjutnya yaitu proses pengorganisasian informasi diisi dengan kegiatan penyampaian materi secara mendalam (inview) dengan mind map. Pada tahapan ini, fasilitator memberikan penjelasan terkait materi dan mencontohkan pembuatan serta penggunaan mind map kepada siswa. Siswa mengamati contoh yang diberikan oleh fasilitator. Selain contoh dari E-JURNAL GAMA JPP fasilitator, siswa juga mengamati cara pembuatan mind map melalui pemutaran video.

Tahap berikutnya yaitu pengulangan informasi yang merupakan bentuk tahapan retensi berisikan kegiatan tanya jawab tentang langkah-langkah pembuatan mind map dan pengulangan materi pelajaran secara singkat. Pada tahap ini, fasilitator juga menerapkan langkah review dalam pembuatan mind map.

Pada tahap terakhir merupakan bentuk tahapan produksi berisikan kegiatan pembuatan mind map oleh siswa. Pada tahap ini siswa memulai dengan menyalin mind map yang dicontohkan guru, membuat mind map secara berkelompok, hingga membuat mind map secara individual. Proses ini memberikan kesempatan pada siswa untuk mendapatkan pengalaman keberhasilan (mastery experience) dengan menggunakan mind map untuk mempelajari bahasa Inggris. Setelah siswa selesai membuat mind map sesuai materi yang ditentukan pada tiap pertemuan, siswa secara perwakilan mempresentasikan hasil mind mapnya di depan kelas. Selama tahapan kelima ini berlangsung, guru juga memberikan umpan balik dan reinforcement berupa pujian sebagai bentuk perwujudan tahap motivasi.

Hal yang membuat penggunaan modul MMFE dapat meningkatkan efikasi diri ialah karena modul ini menerapkan metode mind map yang dapat membantu siswa untuk lebih mudah menyerap dan menyampaikan kembali materi pelajaran yang diterima (Buzan, 2006). Siswa mengatakan bahwa dengan menggunakan mind map menjadikan lebih mudah mengingat kosa kata, memahami arti, dan mengerti materi secara keseluruhan. Kemudahan ini menjadikan siswa 
memiliki pengalaman keberhasilan (mastery experience) terhadap pelajaran bahasa Inggris. Adanya pengalaman keberhasilan yang berkelanjutan dapat membuat efikasi diri siswa meningkat (Bandura, 1997).

Pemberian intervensi dalam penelitian ini juga melibatkan sumber efikasi diri lainnya yaitu vicarious learning, verbal persuasion, serta physiological and affective states. Penggunaan mind map dalam pembelajaran bahasa Inggris dapat membantu siswa dalam mengingat dan menyampaikan kembali materi pelajaran. Keberhasilan siswa dalam mempelajari bahasa Inggris dengan menggunakan mind map tersebut dapat meningkatkan efikasi dirinya (Khatib \& Maarof, 2015; Sulthon, 2014). Selanjutnya, siswa dapat belajar dari pengalaman keberhasilan orang lain yaitu fasilitator dan teman sekelasnya yang mampu menggunakan mind map untuk membantu belajar bahasa Inggris. Saat ada teman yang berhasil dan dianggap memiliki kemampuan yang sama dengan diri siswa, maka efikasi diri siswa tersebut dapat meningkat (Dwitantyanov, Hidayati, \& Sawitri, 2010). Persuasi verbal yang diberikan oleh fasilitator berupa umpan balik dan pujian selama siswa belajar menggunakan mind map juga dapat meningkatkan efikasi diri siswa (Rahemi, 2007; Ellsworth \& Seguin, 2009). Pada akhirnya, kondisi siswa yang lebih bersemangat dan senang mengikuti pelajaran juga memengaruhi efikasi diri bahasa Inggris siswa.

Proses pembelajaran secara observational learning diketahui sesuai dengan tingkat pemahaman siswa SMP. Hal ini dikarenakan siswa kelas VII SMP yang sedang dalam masa remaja dianggap telah memiliki kemampuan kognitif operasional formal yang sudah mampu untuk berpikir secara abstrak, menalar 96 secara logis, dan menarik kesimpulan dari informasi yang diberikan.

Sebelum diberikannya perlakuan, siswa merasakan kesulitan menghafalkan dan mengingat arti kata. Setelah mengikuti intervensi siswa menjadi lebih mudah memahami dan menghafal materi pelajaran bahasa Inggris. Selain itu, siswa merasakan lebih asyik dan bersemangat saat belajar menggunakan mind map.

Penggunaan mind map sebagai salah satu strategi belajar secara terus menerus dapat membantu meningkatkan efikasi diri siswa dan mencapai prestasi yang diharapkan. Hal ini seperti yang dijelaskan oleh Kim, Wang, Ahn, \& Bong (2015) yang menyatakan bahwa siswa yang memiliki efikasi diri tinggi akan lebih sering menerapkan strategi belajar untuk mencapai tujuan yang ingin dicapainya.

Pelaksanaan penelitian ini memiliki beberapa keterbatasan. Pemilihan subjek dalam penelitian ini tidak didahului dengan tes yang dapat mengungkap kemampuan siswa dalam bidang bahasa Inggris. Bakat dan potensi yang dimiliki siswa dapat menjadi salah satu tolak ukur keberhasilan dalam bidang tertentu (Ball, Lohaus, \& Miebach, 2006). Selain itu, selama penelitian terdapat 2 siswa yang tidak mengikuti kegiatan dari awal hingga akhir karena tidak masuk sekolah. Waktu intervensi yang dilaksanakan setelah upacara dan pelajaran olahraga membuat siswa sedikit kelelahan dalam mengikuti intervensi. Keterbatasan berikutnya yaitu tidak adanya follow up pada kelompok eksperimen dan kontrol. Pemberian follow up penting dilakukan untuk mengetahui ketahanan peningkatan atau pencapaian perubahan setelah mendapat intervensi (Martin dan Pear, 2003).

\section{Kesimpulan}

E-JURNAL GAMA JPP 
Modul Mind Map for English (MMFE) yang disusun berdasarkan pendekatan observational learning valid secara isi dan empirik untuk meningkatkan efikasi diri bahasa Inggris siswa kelas VII SMP. Penggunaan modul MMFE dapat memberikan pengalaman keberhasilan, menjadikan siswa belajar dari pengalaman siswa lain, mendapatkan persuasi verbal dari guru ataupun teman sebayanya, dan dapat menciptakan kegiatan belajar yang lebih menyenangkan. Penggunaan modul MMFE memberikan kontribusi sebesar $22,9 \%$ terhadap peningkatan efikasi diri bahasa Inggris siswa. Selain metode belajar, efikasi diri bahasa Inggris juga dapat dipengaruhi oleh faktor kepribadian siswa, sikap siswa terhadap bahasa Inggris, dan frekuensi pengalaman keberhasilan dalam mata pelajaran bahasa Inggris.

\section{Saran}

Modul Mind Map For English (MMFE) terbukti memiliki validitas isi dan empirik yang baik sehingga dapat digunakan dalam pembelajaran bahasa Inggris kelas VII SMP dengan catatan dilakukan oleh fasilitator sesuai dengan kualifikasi dalam penelitian ini. Saran bagi sekolah yaitu agar dapat memberikan metode pembelajaran yang membantu siswa untuk lebih mudah dalam mengingat dan menyampaikan kembali materi yang diberikan, salah satunya melalui metode mind map. Bagi peneliti selanjutnya, dapat melakukan replikasi penelitian untuk menguji efektivitas modul MMFE sehingga modul dapat digunakan pada kelompok yang lebih luas. Selain itu peneliti selanjutnya diharapkan dapat mengatasi keterbatasan yang muncul dalam penelitian ini yaitu mempertimbangkan waktu intervensi yang lebih kondusif bagi siswa dan E-JURNAL GAMA JPP melakukan follow up untuk mengetahui ketahanan perubahan efikasi diri bahasa Inggris siswa. Penelitian selanjutnya dapat mengembangkan modul untuk mengetahui sejauh mana efikasi diri dapat memengaruhi pencapaian prestasi bahasa Inggris siswa.

\section{Kepustakaan}

Ahmad, J., Amat, M. A. C, Yahya, S. N., Yusof, R., Alias, S. R. (2011). The construction, validity, reliability, and effectiveness of drug rehabilitation module on self-concept of female addicts and motivation achievement of male addicts in Malaysia. International Journal of Humanities and Social Science, 1, 217-228.

Azwar, S. (2014). Penyusunan skala psikologi (Edisi 2). Yogyakarta: Pustaka Pelajar.

Ball, J., Lohaus, A., \& Miebach, C. (2006). Psychological adjustment and school achievement during transition from elementary to secondary school. Zeitschrift fur EntwicklungsPsychologie und Padagogische Psychologie, 38(3), 101-109.

Bandura, A. (1997). Self-efficacy: The exercise of control. New York: W.H. Reeman and Company.

Baron, R. A., \& Byrne, D. E. (2004). Social Psychology 10th Edition. USA: Pearson.

Buran, A., \& Filyukov, A. (2015). Mind mapping technique in language learning. Procedia-Social and Behavioral Sciences, 206, 215-218.

Buzan, T. (2006). Buku pintar mind map (Terjemahan). Jakarta: PT. Gramedia Pustaka Utama.

Creswell, J. W. (2012). Educational research: Planning, conducting, and evaluating 
quantitative and qualitative research 4 th Ed. Boston: Pearson.

Dwitantyanov, A., Hidayati, F., \& Sawitri, D. R. (2010). Pengaruh pelatihan berpikir positif pada efikasi diri akademik mahasiswa (studi eksperimen) pada mahasiswa fakultas psikologi UNDIP Semarang. Jurnal Psikologi Undip, 8(2), 135-144.

Ellsworth, A., \& Seguin, D. G. L. (2009). In retrospect: Is youth grade retention associated with self esteem and self efficacy in early adulthood?. International Journal of Adolescence and Youth, 15, 1-18.

Ersanli, C. Y. (2015). The relationship between students academic selfefficacy and language learning motivation: A study of 8th graders. Procedia Social and Behavioral Sciences, 199, 472-478.

Fadhilah, S. S., \& Nurjayanti, E. (2013). Model bimbingan belajar melalui teknik mind map untuk mengatasi kesulitan mempelajari bahasa. Jurnal. Diunduh pada 28 April 2016 dari www.jurnal.fkip.uns.ac.id/index.php / counsilium /article /download /2958 /2027.

Fun, C. S., \& Maskat, N. (2010). Teachercentered mind mapping vs studentcentered mind mapping in the teaching of accounting at pre-u level -an action research. Journal Procedia Social and Behavioral Sciences, 7(C), 240-246.

Jamaludin, A., Sulaiman, T., Abdullah, S. K., \& Shamsuddin, J. (2009). Building a customized module for the treatement of drug addiction under the remedial program to the implemented on immater at the drug rehabilitation centers in Malaysia, US, and China. Education Review, 6 (11), 57-64.
Jinks, J., \& Morgan, V. (1999). Children's perceived academic self-efficacy: An inventory scale. The Clearing House: A Journal of Educational Strategies, Issues and Ideas, 72(4), 224-230.

Kaplan, R. M. \& Saccuzzo, D. P. (2009) Psychological testing principles, applications, and issues 7th edition. Belmont, CA.: Wadsworth.

Khatib, F. M. M., \& Maarof, N. (2015). Selfefficacy perception of oral communication ability among English as a Second Language (ESL) technical students. Procedia-Social and Behavioral Sciences, 204, 98-104.

Kim, D. H., Wang, C., Ahn, H. S., \& Bong, M. (2015). English language learners self-efficacy profiles and relationship with self-regulated learning strategies. Journal Learning and Individual Differences, 38, 136-142.

Kiong, T. T., Yunos, J. B. M., Mohammad, B. B., Othman, W. B., Heong, Y. M., \& Mohammad, M. M. B. (2012). The development and evaluation of the qualities of Buzan mind mapping module. Journal Procedia-Social and Behavioral Sciences, 59, 188-196.

Liana, A. F., Setyadi, B., \& Herpratiwi. (2015). Peningkatan kemampuan menulis teks recount bahasa inggris menggunakan mind mapping di kelas VIII Sekolah Menengah Pertama Gula Putih Mataram Lampung Tengah. Jurnal. Diunduh pada 22 April 2016 dari http://download.portalgaruda.org/ar ticle.php

Magogwe, J. M., \& Oliver, R. (2007). The relationship between language learning strategies, proficiency, age and self-efficacy beliefs: A study of language learners in Botswana. System, 35, 338-352. 
Mahyuddin, R. M., Elias, H., Cheong, L. S., Muhamad, M. F., Noordin, N., \& Abdullah, M. C. (2006). The relationship between students' selfefficacy and their english language achievement. Jurnal Pendidik dan Pendidikan, 21, 61-71.

Martin, G., \& Pear, J. (2003). Behavior modification what it is and how to do it (7th edition). New Jersey: Pearson Education International.

Noer, M. (2011). Belajar membuat mind map untuk anak - liburan keluarga. Diunduh dari https://www.youtube.com/watch?v= RT-8TKG2ncA\&t=36s

Nurani, G. A. (2015). Efektivitas penggunaan mind map dalam pembelajaran terhadap efikasi diri matematika. Tesis. Universitas Gadjah Mada, Yogyakarta.

Peraturan Menteri Pendidikan dan Kebudayaan Republik Indonesia No. 64 Tahun 2013, tentang Standar Isi Pendidikan Dasar dan Menengah

Peraturan Menteri Pendidikan dan Kebudayaan Republik Indonesia No. 24 Tahun 2016, tentang Kompetensi Inti dan Kompetensi Dasar

Puspasari, D. A., Kuwato, T., Wijaya, H. E. (2012). Dukungan sosial dan adversity quotient pada remaja yang mengalami transisi sekolah. Jurnal Psikologika, 17(1).

Rahemi, J. (2007). Self-efficacy in English and Iranian Senior High School Students majoring in humanities. Journal Novalitas-Royal, 1(2), 98-111. ISSN: 1307-4733.
Rahmatiah. (2014). Meningkatkan hasil belajar bahasa Inggris melalui penerapan pengajaran remedial. Jurnal Nalar Pendidikan 2(2), 222.

Rita \& Situmorang, J. (2014). Pengembangan pembelajaran multimedia interaktif berbasis internet pelajaran bahasa Inggris. Jurnal Teknologi Informasi $\mathcal{E}$ Komunikasi dalam Pendidikan, 1(2).

Santrock, J. W. (2011). Life span development thirteenth edition. New York : McGraw Hill Inc.

Snowman, J., \& McCown, R. (2012). Psychology Applied to Teaching (13th Edition). USA: Wadsworth, Cengage learning.

Sulthon. (2014). Membangun efikasi diri untuk meningkatkan performansi siswa di sekolah. Elementary, 2(2), 251-267.

Wang, C. \& Pape, S. J. (2007). A probe into three chinese boys self-efficacy beliefs learning english as a second language. Journal of Research in Childhood Education 21(4), 364.

Yanuswantoro, D. T. (2015). Peran konselor untuk membantu siswa yang mengalami kesulitan belajar bahasa Inggris di SMPN 2 Wlingi Kabupaten Blitar. Jurnal Penelitian Pendidikan Bimbingan Konseling, 1-9.

Yapono, F., \& Suharnan. (2013). Konsep diri, kecerdasan emosi, dan efikasi diri. Persona Jurnal Psikologi Indonesia, 2(3), 208-216.

Zipp, G., \& Maher, C. (2013). Prevalence of mind mapping as a teaching and learning strategy in physical therapy curricula. Journal of the Scholarship of Teaching and Learning, 13(5), 21-32. 